\title{
Pegivirus humano: Potencial patogénico y riesgo de desarrollo de linfoma no Hodgkin
}

\author{
Johanna C. Arroyave-Ospina, María Fernanda Caicedo, María Cristina Navas y Fabián M. Cortés-Mancera
}

\section{Human Pegivirus: Pathogenic potential and non-Hodgkin lymphoma development risk}

Facultad de Ciencias Exactas Aplicadas. Grupo de Investigación e Innovación Biomédica - GI2B (JCAO, FMC).

Estudiante del Programa Ingeniería Biomédica (MFC) Universidad de Antioquia.

Medellín, Colombia. Facultad de Medicina Grupo de Gastrohepatología (JCAO, MCN,

FMC).

Los autores declaran no tener conflicto de interés.

Financiación. Instituto Tecnológico Metropolitano, Dirección de Investigaciones. Código del proyecto: P14225.

Recibido: 20 de mayo de 2017 Aceptado: 8 de febrero de 2018

Correspondencia a: Fabian M. Cortés-Mancera fabiancortes@itm.edu.co

\section{Introducción}

E 1 pegivirus humano $(\mathrm{HPgV})$, es un virus $\mathrm{ARN}$ de cadena positiva perteneciente a la familia Flaviviridae, género Pegivirus ${ }^{1}$. Este agente se transmite vía parenteral y sexual, siendo los linfocitos la principal célula blanco ${ }^{2}$. $\mathrm{HPgV}$ está relacionado filogenéticamente con el virus de la hepatitis $\mathrm{C}(\mathrm{VHC})$, el cual pertenece a la misma familia pero dentro de un género diferente (Hepacivirus). Además de compartir homología en su organización genómica con VHC, el HPgV tiene la capacidad de generar infección persistente y también de modular la respuesta inmune innata ${ }^{3-5}$.

A la fecha, no se ha demostrado una asociación directa entre la infección por el $\mathrm{HPgV}$ y el desarrollo de enfermedad en humanos. En este sentido, el tamizaje de la infección por $\mathrm{HPgV}$ en los servicios clínicos y en bancos de sangre no está reglamentado. Actualmente se estima alrededor de 750 millones de infectados por $\mathrm{HPgV}$, con una prevalencia global de $1,7 \%$ que varía dependiendo de la región geográfica. En países industrializados de Europa y Norteamérica 1 a $5 \%$ de la población general presenta marcadores de infección para el HPgV. En regiones de países en vía de desarrollo como África y Latinoamérica la prevalencia de $\mathrm{HPgV}$ puede ser de hasta $20 \%{ }^{6}$. En individuos infectados por $\mathrm{VHC}$ la prevalencia es mayor, y de manera característica en personas con infección por virus de la inmunodeficiencia humana (VIH), la coinfección con $\mathrm{HPgV}$ es alta, con un rango entre 15 y $50 \%{ }^{4}$. Con base en la información arriba descrita, es posible concluir que en el mundo la infección por HPgV está ampliamente distribuida, que se presenta una frecuencia mayor en individuos con factores de riesgo para la adquisición de agentes transmitidos vía parenteral, por lo cual es importante determinar si este virus podría estar asociado al desarrollo de alguna enfermedad en el hombre.

El HPgV tiene la capacidad de producir una infección persistente en alrededor de $25 \%$ de los individuos infec$\operatorname{tados}^{1}$, y se ha demostrado que puede ser detectado por períodos de hasta 16 años ${ }^{7}$. Sin embargo, se han realizado muy pocos estudios en relación al potencial patogénico de este virus. En este sentido, estudios epidemiológicos han reportado que la infección por HPgV podría estar relacionada con el desarrollo de enfermedades linfoproliferativas, neoplasias hematológicas, y particularmente con linfoma no Hodgkin (LNH) ${ }^{8,9}$. Lo anterior podría estar vinculado con un potencial patogénico del $\mathrm{HPgV}$, teniendo en cuenta su capacidad de persistencia en el hospedero y su estrecha relación filogenética con el VHC, el cual sí presenta una asociación demostrada con el desarrollo de cáncer de hígado. Además, el VHC es considerado por la Agencia Internacional para la Investigación en Cáncer 
(en inglés International Agency for Research on CancerIARC) como un agente carcinógeno clase I con suficiente evidencia en humanos para el desarrollo de linfoma. Sin embargo, para el HPgV los resultados acerca de su relación con el desarrollo de linfoma son controversiales o no concluyentes ${ }^{10,11}$. El presente artículo está enfocado en la descripción de los aspectos más relevantes de HPgV y la discusión de su potencial patogénico, así como al análisis de los estudios que exploran una asociación con el desarrollo de LNH.

\section{Generalidades del pegivirus humano (HPgV)}

\section{Descubrimiento y clasificación}

Los primeros estudios del $\mathrm{HPgV}$ se remiten al año 1967, cuando el investigador Friedrich Deinhardt y colaboradores realizaban investigaciones sobre casos de pacientes con hepatitis no A, no B. Utilizando un modelo de monos Titís (Saguinus Labiatus), se inoculó suero de un individuo que había presentado un cuadro de hepatitis de etiología desconocida. Posteriormente a la inoculación, estos monos presentaron manifestaciones clínicas de hepatitis, acompañado de la elevación de las enzimas hepáticas y cambios histológicos en el hígado. Al realizar pases de inoculación sucesivos, se demostraría la presencia de un agente transmisible causante de hepatitis (Agente GB). Sin embargo, en ese momento no se continuaron estudios de identificación debido a la falta de técnicas especializadas. Con el advenimiento de las metodologías de biología molecular, en 1995 fueron nuevamente analizadas muestras de los monos inoculados, lográndose identificar la secuencia de dos agentes virales relacionados que fueron denominados GBV-A y GBV-B por su relación con el agente GB, los que fueron incluidos en la familia Flaviviridae ${ }^{12}$. En la actualidad se sabe que estos dos virus tienen la capacidad de infectar especificamente a primates ${ }^{13}$, aunque sólo GBV-B está relacionado con el desarrollo de hepatitis en estos animales. Simultáneamente en 1995, Simons y cols. identificaron un tercer agente, en muestras humanas con hepatitis no A, no B, no C. Este virus presentó una diferencia de $43,8 \%$ con las secuencias de GBV-A y de $28,4 \%$ con GBV-B, por lo que se denominó virus GB tipo $\mathrm{C}(\mathrm{GBV}-\mathrm{C})^{14}$. En otro estudio independiente en 1996, se detectó aparentemente un nuevo virus en un paciente que presentaba un cuadro de hepatitis crónica de etiología desconocida. Este virus fue denominado virus de la hepatitis G (HGV); sin embargo, al realizar los análisis de secuencias se demostro una alta homología (95\%) con el virus GBV-C reportado anteriormente por Simons y cols. en 1995, por lo que se determinó que se trataba de dos aislados del mismo virus ${ }^{15,16}$. Finalmente, se terminó confirmando la clasificación del GBV-C/HGV dentro de la familia Flaviviridae. Debido a la capacidad para generar infección persistente se clasificó en el nuevo género Pegivirus, y se denominó pegivirus humano.

\section{Organización genómica y replicación}

El HPgV posee un genoma ARN de cadena sencilla, con polaridad positiva, de aproximadamente $9,3 \mathrm{~kb}$ y un único marco de lectura abierto (ORF). La organización del genoma es muy similar a la del VHC, presentando una región no codificante en el extremo 5' (5'UTR, del inglés: untranslated region), que conforma la estructura secundaria IRES (del inglés: internal ribosome entry site). Este sitio al inicio del genoma le permite interactuar directamente con el ribosoma y modular la traducción del genoma viral. Así mismo, el genoma de $\mathrm{HPgV}$ también posee una región no codificante en el extremo 3' (3'UTR), la que no presenta repeticiones de adenina (poli-A) o uracilos (poli-U) ${ }^{17}$.

A partir del genoma del HPgV se traduce una poliproteína de aproximadamente 3.000 aminoácidos, la que es procesada proteolíticamente en nueve proteínas: dos proteínas estructurales que corresponden a las glicoproteínas E1 y E2, que hacen parte de la envoltura viral y siete no estructurales que corresponden a p5.6, NS2, NS3, NS4A, NS4B, NS5A y NS5B, destacando la proteína NS3 con actividad helicasa y serina-proteasa, NS5A una fosfoproteína que media la evasión a la respuesta inmune, y de la cual se presume es indispensable para la replicación viral, y NS5B con actividad ARN polimerasa dependiente de ARN. Según estudios de microscopia se ha demostrado que las partículas virales del $\mathrm{HPgV}$ tienen en su estructura una cápside presente; sin embargo, hasta el momento no se ha logrado confirmar la secuencia de esta proteína, su conformación estructural o la región genómica que la codifica $^{18}$. En la Figura 1 se muestra una representación gráfica del genoma del $\mathrm{HPgV}$.

Del ciclo replicativo del $\mathrm{HPgV}$ no hay muchos estudios publicados, pero se ha postulado el modelo con base en el conocimiento del proceso de replicación en VHC y de otros flavivirus. Brevemente, en la primera etapa se da la entrada del virus a su célula blanco mediante la interacción de las glicoproteínas de envoltura viral (E1/2) y el receptor celular. En este punto se han propuesto algunos receptores dependiendo de las células infectada; sin embargo, ha sido demostrado a nivel in vitro que $\mathrm{HPgV}$ puede ingresar no únicamente como partícula viral sino en componentes microvesiculares que contengan el genoma. Esto explicaría en parte el amplio número de células donde ha sido demostrado la replicación activa de este agente ${ }^{19}$. Posteriormente, ocurre la descapsidación y la liberación del ARN genómico en el citoplasma de la célula, la que da lugar a la traducción dependiente de la secuencia IRES ubicado en la región 5'UTR del $\mathrm{HPgV}$, generando así la poliproteína viral precursora. Luego, se adelanta el 


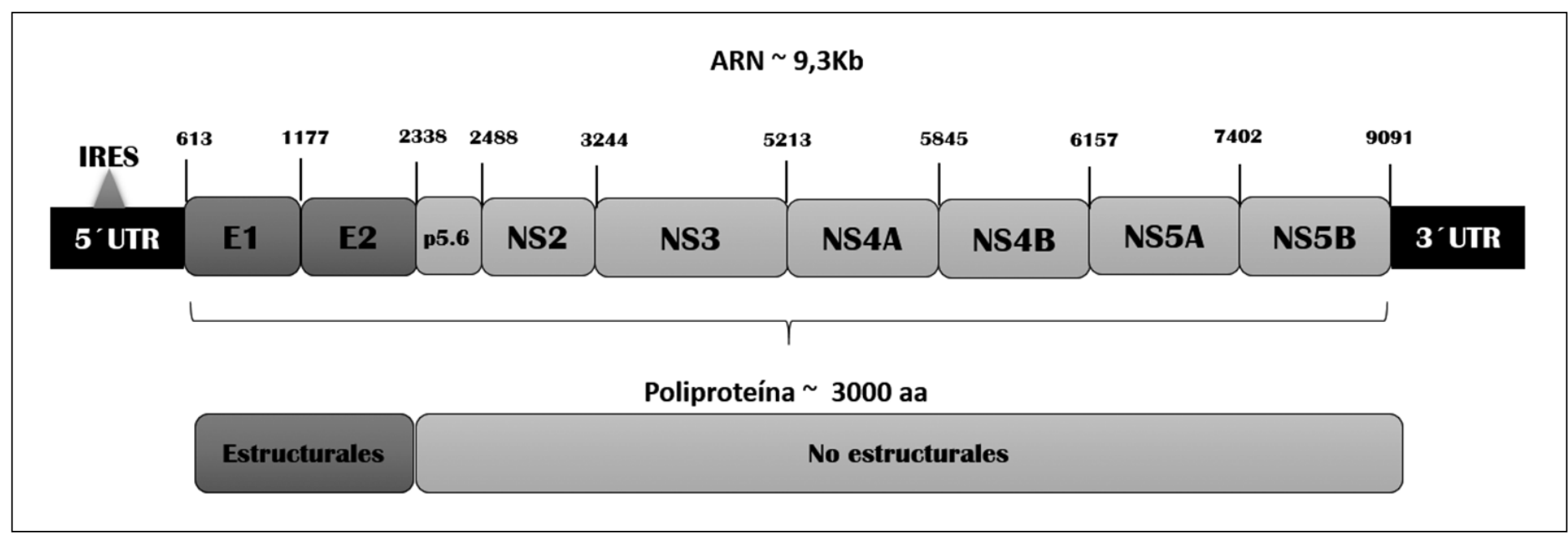

Figura 1. Esquema representativo de la estructura del genoma del HPgV. Se muestra un genoma ARN de 9,3 kilobases (kb) que presenta regiones no codificantes (UTR; del inglés unstranslated regions) en los extremos 5' y $3^{\prime}$. Se destaca en el extremo 5'UTR (556 nucleótidos), una estructura secundaria denominada IRES (sitio interno de entrada al ribosoma), la cual regula la traducción de una poliproteína viral de aproximadamente 3.000 aminoácidos (aa). Esta poliproteína es procesada por enzimas virales y celulares que dan lugar a las glicoproteínas de envoltura E1-E2 (proteínas estructurales), a la proteína de 6 KDa (p5.6) y a las proteínas no estructurales NS2-NS5b. Los números en la parte superior indican la posición en nucleótidos de los segmentos codificantes según la nomenclatura de Worobey y Holmes en 2001 (Stapleton et al., 2011; Arroyave et al., 2013).

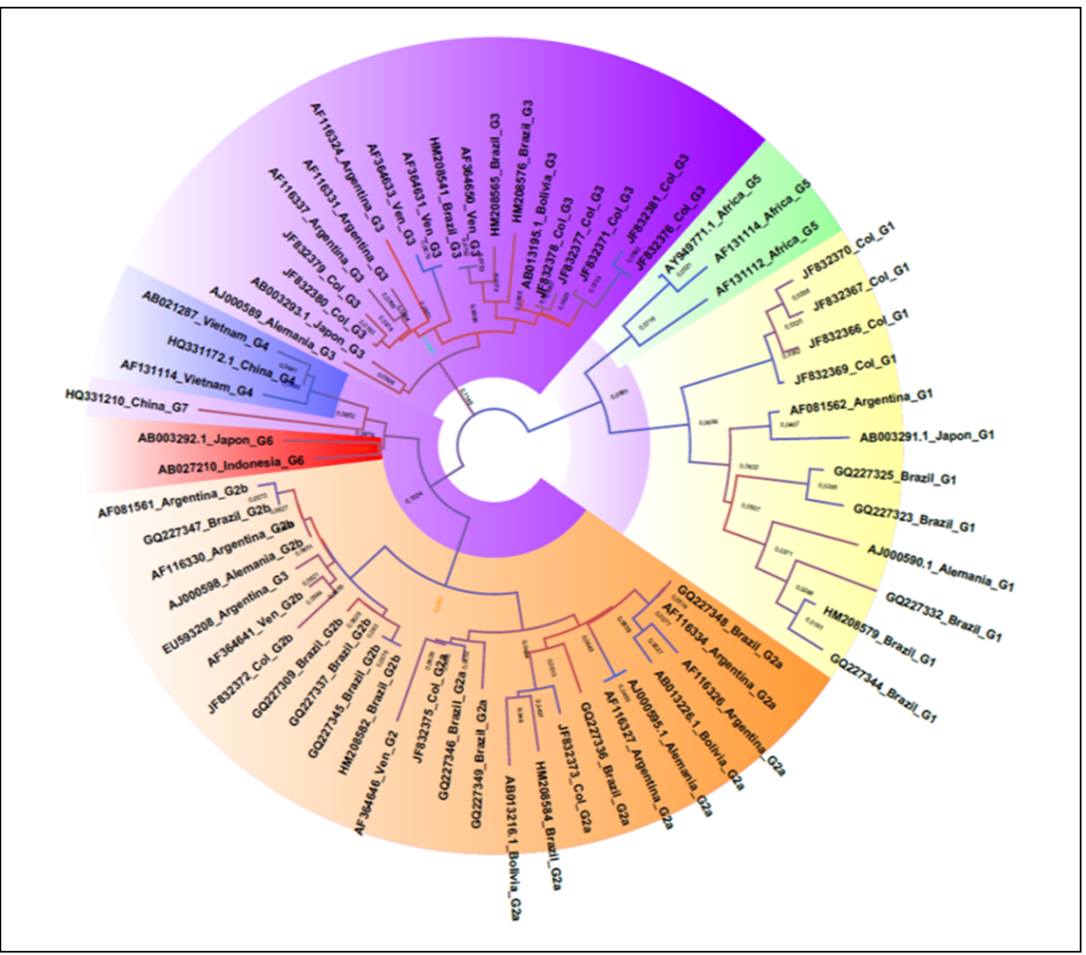

Figura 2. Diversidad genética de HPgV. Árbol radial sin raíz generado con el programa MEGA 5.0, utilizando secuencias prototipos de la región 5'UTR de los siete genotipos del GBV-C disponibles en el GenBank. Los números en las ramas internas obedecen a los valores de bootstrap generados a partir de 1.000 repeticiones, utilizando el método de máxima parsimonia y el modelo de evolución Kimura 2 parámetros más Gamma. Con colores se resalta cada genotipo viral. En la identificación de las secuencias se puede observar el código de acceso GenBank seguido del país de aislamiento y el genotipo/subgenotipo respectivo. La visualización y edición del árbol generado se realizó en el programa FigTree v1.4.3. procesamiento y maduración de las proteínas, gracias a proteasas celulares y proteínas virales como NS3 y NS4A. Finalmente, una vez generadas nuevas copias del genoma a partir de ARN de cadena negativa, las partículas virales se ensamblan y se liberan de la célula por gemación ${ }^{20}$.

\section{Diversidad genética de $\mathrm{HPgV}$}

Algunos aspectos importantes acerca de la distribución de HPgV hacen énfasis a varios estudios filogenéticos, los que proponen la hipótesis de que $\mathrm{HPgV}$ se originó en el continente africano, presentando una cercana evolución con su hospedero ${ }^{1,21}$. Como se muestra en la Figura 2, hasta el momento se han caracterizado siete genotipos con algunos subgenotipos, de los cuales se presenta una divergencia de aproximadamente $14 \%{ }^{22}$. Inicialmente, tres genotipos del $\mathrm{HPgV}$ fueron descritos: en África el genotipo 1, que se divide en cinco subgenotipos, en América del Norte y Europa el genotipo 2 y se divide en tres subgenotipos, y en Japón el genotipo $3^{23}$; luego se identificó el genotipo 4 en Myanmar y Vietnam ${ }^{24}$, seguido del genotipo 5 en Sudáfrica. Al genotipo 6 corresponden a secuencias identificadas en Indonesia, y recientemente se encontró el genotipo 7 en el sudeste de Asia ${ }^{25,26}$. En la Figura 2 se observa la agrupación filogenética de los diferentes genotipos descritos para $\mathrm{HPgV}$.

En América Latina son escasos los estudios que revelan la diversidad genética del HPgV. Según estos trabajos, se ha determinado la presencia de los genotipos 1, 2 y 3 en Venezuela, Brasil, Argentina, Bolivia y Colombia principalmente. En Brasil, donde se han realizado la mayor cantidad de trabajos, casi todos se han adelantado en el 
contexto de la coinfección $\mathrm{HPgV}$ y VIH ${ }^{27}$. Por su parte en Colombia, se han descrito prevalencias dependientes de la población analizada. El estudio más reciente publicado en el año 2011 por Alvarado y cols. incluyó muestras de donantes de sangre y de poblaciones indígenas colombianas $^{26}$. En este trabajo se reportaron los genotipos 1, 2a, 2 b y 3 del $\mathrm{HPgV}$, arrojando la mayor prevalencia la infección por el genotipo $2 \mathrm{a}$ en donantes. En contraste, los resultados del análisis en tribus indígenas (Wayuu, Kamsa e Inga) / (Departamento de Amazonas) reportaron una alta prevalencia del genotipo 3, confirmando resultados de estudios previos en población amerindia ${ }^{26,28}$. Es importante resaltar, que a pesar de la diversidad genética que presenta $\mathrm{HPgV}$, con diferencias señaladas en la secuencia entre genotipos, no existe a la fecha la primera publicación en el mundo donde se explore la contribución de este factor con la etnia del individuo (ancestría) y el desarrollo de LNH.

\section{Tropismo de HPgV}

Las principales vías para adquirir la infección por el $\mathrm{HPgV}$ son la exposición a sangre vía parenteral, transfusión de hemoderivados contaminados, realización de piercing, tatuajes y contacto sexual. Debido a que comparte el mismo modo de transmisión que $\mathrm{VHC}$, virus de hepatitis $\mathrm{B}$ (VHB) y VIH, es común encontrar coinfección de estos virus con el $\mathrm{HPgV}^{20}$.

Para hacer el diagnóstico de la infección por HPgV se puede realizar la detección de anticuerpos específicos contra la proteína E2 (anti-E2), mediante prueba de
ELISA (inmuno-ensayo acopado a enzima) ${ }^{29,30}$. También, es posible realizar la detección del ARN viral por medio de técnicas moleculares como la reacción de polimerasa en cadena con transcriptasa reversa (RPC-TR). La infección por $\mathrm{HPgV}$ es autolimitada en la mayoría de individuos inmunocompetentes antes de dos años, lo que es evidenciado por el aclaramiento viral y producción de anticuerpos neutralizantes contra la proteína E2 (Figura 3); en contraste, el virus puede establecer una infección persistente por largos períodos de tiempo en algunos pacientes $^{31}$. Aunque si un paciente es capaz de hacer un aclaramiento de la infección, es usual encontrar un nivel mayor de anti-E2 y ausencia de genoma viral, por lo que ambas técnicas (ELISA y RPC-TR) son esenciales para determinar en qué estadio se encuentra la infección ${ }^{32}$.

$\mathrm{El} \mathrm{HPgV}$ es el agente viral que infecta a humanos de más alta similaridad con VHC. Se ha reportado hasta $29 \%$ de homología en su región codificante. Con base a esta relación, desde los inicios se propuso la posibilidad de que $\mathrm{HPgV}$ fuese un virus hepatotrópico, debido a que el virus fue detectado en este tejido ${ }^{33,34,35}$. Sin embargo, la detección de ARN viral de polaridad negativa en tejido hepático no fue claramente demostrada, ni tampoco la presencia de cambios histológicos o bioquímicos en tejido hepático de pacientes monoinfectados por $\mathrm{HPgV}^{18,36,37,38}$. En uno de los estudios realizados en 1998 se cuantificó el ARN genómico de $\mathrm{HPgV}$ y de VHC, tanto en explantes hepáticos, como en muestras de suero de pacientes antes del trasplante ${ }^{33}$. En este reporte se encontró que las concentraciones de ARN del VHC de todos los

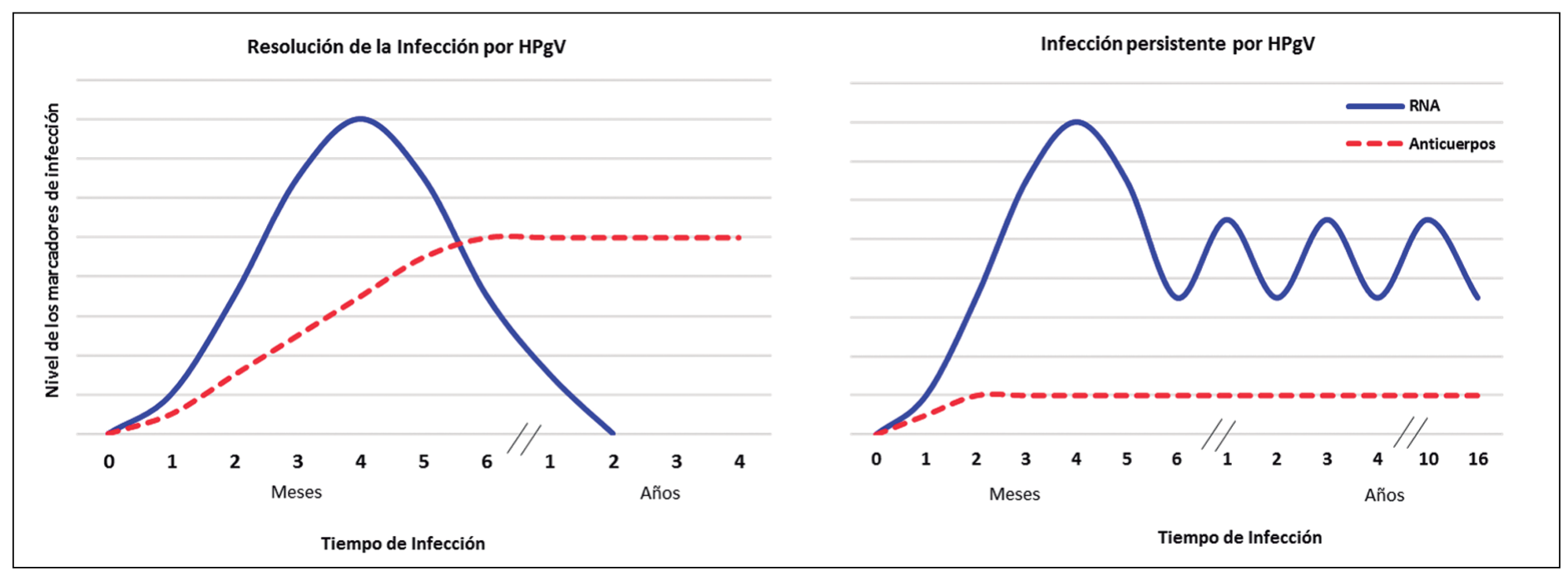

Figura 3. Cinética de marcadores de infección por HPgV. En el panel izquierdo se observa el tipo de infección más frecuente por HPgV, la que puede documentarse hasta en $75 \%$ de los casos. La resolución de la infección culmina con el aclaramiento viral (ARN indetectable) antes de dos años post-infección, así como con el aumento en el título de anticuerpos neutralizantes anti-E2 de HPgV. En la Figura de la derecha se representa la cinética de marcadores durante una infección persistente por HPgV. EI ARN viral es detectable por períodos de tiempo mayor a dos años en alrededor de $25 \%$ de los individuos; los niveles de ARN viral pueden ser variables y los niveles de anticuerpos neutralizantes anti-E2 son generalmente indetectables (Msuko, K, Mitsui T, Iwano K, 1996). 
pacientes fueron significativamente más altas en el hígado que en muestras de suero, mientras que para HPgV fue inversa la relación. A pesar de que se llegó a encontrar una pequeña cantidad de ARN de HPgV en muestra de hígado, los autores hipotetizaron que la detección del genoma de $\mathrm{HPgV}$ en estas muestras podría haberse dado por la presencia de componentes sanguíneos en el tejido hepático ${ }^{33}$. Con el fin de determinar el sitio de replicación no hepática de $\mathrm{HPgV}$, se analizó la presencia del genoma y el ARN viral de cadena negativa de $\mathrm{HPgV}$ en células sanguíneas. En un trabajo in vitro reportado en 1999 por Fogeda y Col, se tomó suero de un individuo con infección confirmada por $\mathrm{HPgV}$ para utilizarlo como inóculo en cultivos primarios de células mononucleares de sangre periférica (en inglés pheripheral blood mononuclear cells-PBMCs). Estos autores encontraron presencia del genoma y cadena negativa a nivel intracelular durante 30 días postinfección, a través de ensayos de RPC-TR, y mediante técnicas de hibridación in situ; además se demostró que el ARN genómico fue 10 veces más abundante que la copia de cadena negativa. Este primer acercamiento se constituyó en evidencia sustancial de la replicación de $\mathrm{HPgV}$ en PBMCs en condiciones in vitro. Al intentar caracterizar las subpoblaciones de que soportan la replicación en personas infectadas con $\mathrm{HPgV}$, se demostró una alta concentración del ARN de $\mathrm{HPgV}$ en linfocitos, siendo en una mayor proporción en linfocitos $\mathrm{B}^{39}$.

Uno de los artículos más recientes sobre el tropismo del HPgV realizado en el año 2014, analizó los niveles de ARN del HPgV en PBMCs. Los resultados de este estudio resaltan la replicación del $\mathrm{HPgV}$ no sólo en linfocitos, sino que además se encontró gran cantidad de ARN del HPgV en células naive (CD3+ CD4+ CD45RA; no activadas) en comparación a células CD4+ de memoria; adicionalmente, ARN fue encontrado en monocitos y células NK (natural killer) al mismo nivel; en este contexto, los investigadores sugieren que la infección de células NK podría contribuir a la instauración de infección persistente, y por lo tanto, podría ser considerado un mecanismo potencial de supresión inmune ${ }^{19,35,40}$. Como se mencionó anteriormente, este amplio espectro de células capaces de soportar la infección por $\mathrm{HPgV}$ podría ser explicado en parte por la existencia de un receptor conservado entre mononucleares que facilite su entrada, pero también por la formación de complejos vesiculares que contienen copias del genoma viral y que pueden ser ingresados a las células vía receptores de lipoproteínas. De otra parte, cuando se han realizado estudios para comparar el nivel de detección del HPgV según el tipo de muestras, los mayores niveles de positividad son arrojados en médula ósea, seguida de PBMCs y muestras de suero, lo que se correlaciona con el tipo de célula blanco y el principal sitio de replicación del $\mathrm{HPgV}^{41,42}$.

\section{Potencial patogénico de $\mathrm{HPgV}$}

Aunque no se conoce a profundidad todos los mecanismo de persistencia en $\mathrm{HPgV}^{43}$, esta cinética de infección se ha atribuido a varios factores como la variabilidad genética, a la infección de mononucleares y a mecanismos de inmunomodulación.

En relación a la variabilidad genética, un estudio publicado por Giménez-Barcons en el año 2000 reportó la presencia de variantes resistentes al tratamiento con interferón en siete paciente con hepatitis $\mathrm{C}$. Al finalizar la terapia, en cinco de los pacientes se observó la misma carga viral a la observada antes de iniciar el esquema. Al evaluar las secuencias 5'UTR y la región NS3, se evidenció la presencia de mutaciones, indicando un proceso de variabilidad genética de selección positiva que podría contribuir al fenómeno de persistencia. Es de aclarar, sin embargo, que ninguna de las mutaciones estuvo presente en los cinco aislados como para explicar el fenómeno de resistencia a interferón ${ }^{44}$. Estudios previos en 1998 desarrollados por Kao y cols., evaluando el efecto del tratamiento combinado de interferón y ribavirina en pacientes co-infectados con VHC, demostraron que este tratamiento combinado tampoco generaba una respuesta viral sostenida. A pesar de que en el trabajo de Kao y cols., no se evaluó la variabilidad genética de $\mathrm{HPgV}$ después del tratamiento, este trabajo indicó la existencia de uno o más mecanismo de persistencia capaces de reestablecer las poblaciones virales luego de cuellos de botellas causados por tratamientos combinados con blancos disímiles ${ }^{45}$. Con el fin de explorar la región responsable en la resistencia a interferón, y develar un posible mecanismo de persistencia derivado de la variabilidad genética de $\mathrm{HPgV}$, en 2005 Xiang y cols., describieron las variaciones en tres regiones genómicas, dos de ellas diferentes a las estudiadas por Giménez Barcons y cols., realizando análisis en pacientes y a nivel de laboratorio ${ }^{5}$. En esta oportunidad Xiang y cols., decidieron evaluar las secuencias de las regiones codificantes para la proteína de envoltura E2 y NS5A, ya que en VHC ambas contribuían con la resistencia a interferón; adicionalmente se analizó la región no codificante 5'UTR. Para el estudio, mediante RPC-TR analizaron la presencia del $\mathrm{HPgV}$ en 65 pacientes con diagnóstico de hepatitis $\mathrm{C}$ antes de iniciar el tratamiento antiviral con interferón. De estos pacientes, nueve estaban coinfectados con $\mathrm{HPgV}$, por lo que se decidió evaluar la cinética de detección en muestra de sangre, antes, durante y después del tratamiento. Según los resultados, en tres de los nueve pacientes no se detectó el genoma en los siguientes seis meses postratamiento (cepas sensibles). En otros dos pacientes no se detectó el genoma durante la terapia, pero presentaron falla una vez terminado el esquema (recaí$d a)$, mientras que en los cuatro restantes el genoma fue detectado en todos los muestreos (cepas resistentes). De 
los aislados detectados, se estudiaron las tres secuencias de los aislados de HPgV resistentes vs una de las cepas sensibles. Luego de comparar las secuencias, se encontró variabilidad en las tres regiones analizadas, pero sólo en NS5A se evidenció un polimorfismo en todas las cepas resistentes, en una localización similar a la reportada para la región ISDR (del inglés interferón sensitivity-determining region) de la proteína NS5A en VHC. Para dilucidar el efecto biológico de este polimorfismo, las secuencias de NS5A fueron clonadas, expresadas y purificadas en un modelo de levadura, demostrando que la región ISDR de esta proteína no estructural proveniente de una cepa del $\mathrm{HPgV}$ resistente al interferón actúa como inhibidor de la proteína PKR, efector principal de la respuesta inmune frente a las infecciones virales.

Además del papel de la proteína NS5A del HPgV en la resistencia a interferón, también se reporta una actividad antiapoptótica e inmunomoduladora por parte de la proteína. Frente a la regulación de la muerte celular programada, ésta fue evaluada en PBMCs de pacientes co-infectados con VIH y HPgV. Luego de cuantificar por citometría el nivel de expresión del ligando de FAS y la actividad apoptótica en linfocitos T, se logró concluir que aquellos individuos con $\mathrm{HPgV}$ presentaron menor actividad y expresión de receptores asociados con la activación de la apoptosis en células $\mathrm{T}$, lo que podría promover la infección persistente del HPgV en estas células y un efecto positivo sobre el desenlace clínico de VIH. Un estudio en 2012, buscó analizar la expresión de citoquinas en PBMCs durante la infección con $\mathrm{HPgV}$ in vivo, y a nivel in vitro usando líneas de linfocitos $\mathrm{T}$ que expresaban la proteína NS5A de $\mathrm{HPgV}$. En el estudio se encontró que cuando las PBMCs estaban infectadas por $\mathrm{HPgV}$, se observó una regulación positiva de las citoquinas IL-2 e IL-12A mientras que la citoquina IL-13 disminuida. A nivel in vitro ha sido demostrado que la proteína NS5A regula también negativamente las citoquinas IL-4, IL-5, IL-10 e IL-13, lo que sugiere que la infección por $\mathrm{HPgV}$, y en particular la proteína NS5A, modula la expresión de citoquinas en las células $\mathrm{T}^{46}$. Otros estudios demuestran que la proteína NS5A, tiene un efecto en el aumento de la liberación del factor del estroma derivada de células 1 (SDF-1), el que se encarga de activar a los leucocitos, regulando la expresión de genes durante la infección por el $\mathrm{HPgV}^{47,48}$. En estudios in vitro con la proteína NS5A del $\mathrm{HPgV}$, se ha descrito reducción de la expresión de citoquinas Th2 (interleuquinas 4, 5, 10 y 13) en PBMCs, y aumento de la expresión de las citoquinas Th1 (interleuquinas 2 y 12) ${ }^{46}$. Aunque estos procesos de modulación inmunológica claramente favorecen la persistencia del $\mathrm{HPgV}$ en el individuo infectado, diversos autores han descrito la capacidad del HPgV para la generación de un efecto inhibitorio asociado con la disminución de la carga viral de VIH, de modo que los pacientes con dicha co-infección presentan un alto recuento de células CD4+, asociado en algunos estudios a mayor tiempo de sobrevida, mejor respuesta a los tratamiento y menor progreso a SIDA ${ }^{49}$. Además de VIH, un estudio que caracterizó la co-infección $\mathrm{HPgV}$ y virus de Ebola, reportó que la sobrevida era mayor, comparada con la sobrevida de pacientes monoinfectados por este Filovirus. En términos generales, este resultado es supremamente relevante, debido a que el virus de Ebola presenta alta tasa de mortalidad, entre 50 y $90 \%$ en el hombre, para la cual hasta el momento no se ha encontrado cura ${ }^{50}$.

Además, de la contribución de la proteína NS5A, también se ha reportado un papel inmunomodulador a las proteínas E2 y NS3 ${ }^{6,51}$. Con respecto a la actividad demostrada para la proteína de envoltura, Stapleton y col. demostraron un nuevo mecanismo nunca antes reportado para un virus ARN persistente. De forma interesante, la proteína E2 fue capaz de afectar la señalización dependiente de los receptores específicos de células $\mathrm{T}$ en modelos in vitro. Por su parte, la proteína NS3 del HPgV es reconocida por su actividad proteasa dentro del ciclo replicativo. Al evaluar el papel que esta proteína podría presentar en la infección persistente, Chowdhury y cols., lograron determinar que la actividad proteolítica de NS3 pudo afectar la función celular asociada a respuesta inmune $^{51}$. Específicamente, la respuesta a interferón es dependiente de mecanismos que reconocen estructuras secundarias de ARN que se presentan durante la replicación de agentes virales. Uno de los componentes de esta vía es la proteína mitocondrial de señalización antiviral (MAVS; por su siglas en inglés). Cuando NS3 entra en contacto con este componente mitocondrial, termina clivando y desactivando este componente.

\section{Relación de HPgV con linfoma no Hodgkin}

El término linfoma se refiere un grupo de patologías malignas que se originan en los nódulos linfoides y otros tejidos linfoides, que agrupa distintos tipos de neoplasias que se originan por la alteración en el desarrollo y la diferenciación de los linfocitos. Alrededor de $80 \%$ de los casos de linfoma diagnosticados corresponden a $\mathrm{LNH}$, el que incluye múltiples subtipos con diferencias en la presentación clínica, epidemiología, etiología y respuesta al tratamiento ${ }^{52}$; estos se clasifican teniendo en cuenta criterios morfológicos, genéticos, moleculares, inmunofenotípicos y características clínicas ${ }^{53}$. El LNH, corresponde al octavo cáncer más frecuente en hombres y el décimo en mujeres, aporta alrededor de 5,1\% del total de casos de cáncer y $2,7 \%$ de muertes asociadas a cáncer a nivel global. En el año 2012 se estimaron 385.700 casos nuevos de LNH y alrededor de 199.700 muertes asociadas en este mismo año, con las incidencias más altas en las regiones del Este y Noreste de Europa, y en Norteamérica (> 
9,1/100.000 habitantes) $)^{54}$. Los datos epidemiológicos de LNH en Latinoamérica son limitados, un estudio reciente indicó que la mayoría de los casos de LNH corresponden a neoplasmas de células $\mathrm{B}$, donde el subtipo más frecuente es el linfoma difuso de células B grandes (en inglés diffuse large B-cell lymphoma-DLBCL) ${ }^{55}$. Latinoamérica aporta aproximadamente $7 \%$ de los casos de LNH a nivel global, con 27.000 casos nuevos estimados y 14.000 muertes asociadas por año, con una tendencia al incremento en la incidencia y en la mortalidad ${ }^{56}$.

En cuanto a la etiología del LNH, diferentes agentes infecciosos de tipo viral (virus Epstein-Barr-VEB, VHC, VHB y VIH) han sido reconocidos como agentes causales de $\mathrm{LNH}^{57-59}$, asociado a la presencia de otros factores de riesgo reconocidos como historia familiar de linfoma, inmunosupresión, edad avanzada (más de 60 años en promedio), factores del estilo de vida (consumo de tabaco, alcohol, obesidad), exposición a carcinógenos químicos, entre otros ${ }^{60}$.

En este sentido, múltiples evidencias soportan que el VHC puede ser un factor de riesgo para el desarrollo de $\mathrm{LNH}^{61}$, y actualmente es considerado por la IARC como un agente carcinógeno con evidencia suficiente en humanos para linfoma no Hodgkin. Estudios analíticos de cohorte y de casos y controles, reportan un incremento significativo en el riesgo relativo de desarrollar LNH asociado a la infección por VHC (RR:2 y RR: 2,5, respectivamente); sin embargo, a la fecha los resultados no son del todo concluyentes y algunos no encuentran asociación estadística, en parte por bajo número de casos, pero además debido a la baja prevalencia de infección por este virus observada en algunas regiones geográficas como el norte de Europa, norte de E.U.A. y Canadá ${ }^{57,62,63}$. En Latinoamérica, se han reportado diferentes frecuencias de infección por VHC dependiendo la población estudia$\mathrm{da}^{64,65}$; sin embargo, existen pocos reportes de prevalencia de infección por $\mathrm{VHC}$ en pacientes con enfermedades linfoproliferativas o enfermedades hematológicas, por lo que no hay evidencia suficiente para concluir si el comportamiento en esta región es similar a lo encontrado en otras regiones de baja prevalencia. Dentro de los factores que explican una relación causa-efecto entre la infección por VHC y el desarrollo de LNH, se ha planteado que el VHC tiene un rol oncogénico en la enfermedad. Lo anterior puede justificarse en la evidencia de la respuesta clínica al tratamiento antiviral de los pacientes con linfoma VHC positivos, en quienes se observa una disminución significativa en el proceso de linfomagénesis ${ }^{66}$. Para explicar este efecto, se proponen al menos tres mecanismos diferentes: la estimulación antigénica de forma crónica que puede estimular la proliferación de las células B; la interacción entre la proteína E2 del VHC y el receptor CD81 que favorece la activación inmune y la proliferación de células $\mathrm{T}$ y B, lo que puede predisponer a alteraciones citogené- ticas (ej. translocaciones); y la transformación directa en linfocitos B infectados por VHC; no obstante, este último aún requiere de evidencia experimental contundente, particularmente debido a que las PMBCs son permisivas para la entrada del virus, pero no se ha demostrado que soporten replicación activa y presencia de intermediarios replicativos ${ }^{61}$. Teniendo en cuenta lo anterior, se sugiere la existencia de mecanismos adicionales que expliquen la relación causa-efecto entre el VHC y el desarrollo de LNH. Una de las hipótesis que podría soportar lo anterior, es que la presencia de otros agentes con modo de transmisión similar al VHC podría estar implicados en el estímulo oncogénico en estos pacientes. Así entonces, teniendo en cuenta la relación filogenética que existe entre el VHC y el HPgV, así como las evidencias de homología estructural y funcional por ejemplo en la proteína NS5A, el planteamiento de que el $\mathrm{HPgV}$ conserve mecanismos que puedan estar relacionados con el desarrollo de LNH es plausible.

Diversos estudios, han reportado altas prevalencias de infección por $\mathrm{HPgV}$ en pacientes con enfermedades hematológicas, trastornos linfoproliferativos y linfoma Hodgkin y no Hodgkin. En general, en estos estudios se observaron frecuencias de infección por $\mathrm{HPgV}$ más altas (8-13\%) que las reportadas en población general y donantes de sangre (2-5\%); sin embargo, estos datos varían dependiendo de la población de pacientes utilizada, así como de los factores de riesgo presentes según la región geográfica de cada estudio ${ }^{67,68}$. Específicamente, estudios descriptivos y analíticos recientes han reportado una posible asociación entre la infección por $\mathrm{HPgV}$ y el desarrollo de enfermedades linfoproliferativas, neoplasias hematológicas, y particularmente en el desarrollo de $\mathrm{LNH}^{8}$; sin embargo, hasta la fecha algunos resultados son controversiales o no concluyentes ${ }^{10,11,69}$ y por lo tanto el rol del $\mathrm{HPgV}$ en el proceso de linfomagénesis no ha sido claramente demostrado. En la Tabla 1 se resumen los principales estudios epidemiológicos que han explorado asociación entre $\mathrm{HPgV}$ y LNH.

Estos resultados controversiales que pueden depender de diferentes factores como las diferencias geográficas, el tipo de muestra analizada, la diversidad genética del virus y otros factores de riesgo asociados como co-infecciones con VHI o VEB, no han sido exploradas con el fin de explicar las diferencias observadas en los estudios. En este sentido, recientemente se reportó una alta frecuencia de infección por $\mathrm{HPgV}$ en pacientes con diferentes neoplasias hematológicas (20\%), en el que se evaluaron muestras de suero, PBMCs y médula ósea, encontrando el mayor porcentaje de detección en médula ósea, seguido por PBMCs. De forma interesante, en este estudio el análisis de variantes virales basado en la región 5'UTR, mostró la existencia de variantes presentes únicamente en médula ósea, variantes presentes únicamente en suero y/o 
Tabla 1. Principales estudios de asociación pegivirus humano y linfoma no-Hodgkin (NHL)

\begin{tabular}{ll}
\hline Tipo de estudio & Hallazgos \\
Estudio descriptivo & En 78,8\% (26/33) de los pacientes con LNH se detectaron an- \\
transversal & ticuerpos anti E2 HPgV versus 35\% (177/506) en los controles. \\
$\mathrm{n}=33$ & Sólo se logró la detección de ARN viral en 1/33 paciente (3\%) \\
Controles $=755$ & versus 7/249 (2,8\%) en los controles
\end{tabular}

Estudio descriptivo transversal

$\mathrm{n}=47$

Estudio descriptivo

transversal

$\mathrm{n}=70$

controles $=70$

Estudio descriptivo

transversal

$\mathrm{n}=120$

controles $=1.443$

Estudio de casos y

controles

$\mathrm{n}=553 \mathrm{y}$

controles $=438$

Estudio de casos y

controles

$\mathrm{n}=137$

controles $=125$

Estudio descriptivo

retrospectivo

$\mathrm{n}=33$

controles $=138$

Frecuencia de 72\% (21/29) de detección de ARN de HPgV (regiones 5' UTR y NS3) en pacientes con neoplasias hematológicas. El 34\% de estos pacientes correspondía a $\mathrm{LNH}$; versus una frecuencia de $42 \%$ (8/19) en pacientes con enfermedades hematológicas no neoplásicas

Se detectó ARN de HPgV en 7,1 vs 1,4\% en los pacientes con $\mathrm{LNH}$ versus los individuos sanos. Se reportó un riesgo relativo de 5,3 veces de desarrollar LNH asociado a la infección por $\mathrm{HPgV}$

Alta prevalencia de ARN de HPgV en pacientes con LNH de células $B(9,2 \%)$ en comparación a donantes de sangre $(0,7 \%)$ y pacientes oncológicos con tumores sólidos $(0,9 \%)$

Se encontró una prevalencia de HPgV de 4,5\% (25/553) en pacientes con LNH en comparación a 1,8\% (8/438) en los controles, con una diferencia estadísticamente significativa. Se reportó un riesgo relativo ajustado de 2,7 veces para el desarrollo de LNH asociado a la infección por HPgV

La prevalencia de anticuerpos anti-E2 de HPgV (13-22\%) en los casos de LNH no tuvo diferencia estadísticamente significativa a la observada en el grupo control

Se reportó una prevalencia de ARN de HPgV en 30,3\% de pacientes seropositivos para $\mathrm{VIH}$ con linfoma ( $\mathrm{LH}$ y $\mathrm{LNH}$ ) versus $23,6 \%$ en pacientes seropositivos para VIH sin linfoma

Estudio de casos y

controles

$\mathrm{n}=658$

controles $=1.316$

\section{Observaciones}

Todos los pacientes analizados presentaban infección por VHC. No se determinó la posible reacción cruzada para la prueba de inmunoensayo, únicamente se analizaron muestras de suero

Se encontró una correlación positiva entre la infección por HPgV y la presencia de anormalidades citogenéticas (estructurales y numéricas) en $64 \%$ de los pacientes

\section{Referencia}

(Civardi et al., 1998)

(Pavlova et al., 1999)

Los resultados no fueron estadísticamente significativos. Se (Kaya et al encontró una baja prevalencia de anticuerpos anti-VHC en la 2002) población analizada $(1,4 \%)$ en pacientes y controles

Baja prevalencia de marcadores de infección por VHC en todos los grupos analizados (0,99-1,9\%)

(Giannoulis et al, 2004).

Todos los pacientes fueron negativos para la infección por $\mathrm{VIH}$. La prevalencia de anticuerpos anti-VHC fue mayor en los individuos positivos para ARN de HPgV. Se reportaron los genotipos 2a, 2b y 3 de HPgV en las muestras del estudio

No se evaluó presencia de ARN de HPgV en las muestras del estudio. Las muestras del grupo control no fueron pareadas de acuerdo a los factores de riesgo y características sociodemográficas

El número de pacientes con LNH fue bajo (26) comparado con otros estudios. Se propone que los resultados de alta prevalencia de HPgV en otras cohortes con LNH dependen de la alteración de base en la respuesta de células T de estos pacientes

Sólo se encontró asociación significativa con LNH en los casos de infección activa por HPgV (detección de ARN viral). se excluyeron pacientes co-infectados con VIH y/o VHC y se demostró que la infección por HPgV precedió el desarrollo de la enfermedad mediante la detección de ARN viral en las muestras antes del diagnóstico de LNH
(Krajden et al. 2010)

(Guidicelli et al., 2011).

(Ernst et al 2011)

(Chang et al. 2014).

HPgV: pegivirus humano. LH: linfoma de Hodgkin. LNH: linfoma no Hodgkin. VHC: virus de hepatitis C.

PBMCs, y variantes presentes en las tres muestras analizadas (suero) $)^{41}$; lo cual podría explicar la discordancia entre resultados de diferentes estudios donde sólo se han analizado muestras de suero y/o PMBCs. Fogeda y cols., demostraron que en $\mathrm{HPgV}$, diferentes variantes virales o cuasiespecies difieren en su sitio de replicación primaria ${ }^{70}$. Adicionalmente, publicaciones actuales indican que el virus puede infectar y replicarse en diferentes subpoblaciones de linfocitos $\mathrm{T}$ y $\mathrm{B}^{19}$.
En 1998 se publicaron los primeros reportes de prevalencia de $\mathrm{HPgV}$ en una cohorte de pacientes con LNH. Inicialmente, se reportó un análisis de 69 muestras de pacientes con $\mathrm{LNH}$, donde se detectó 13\% (9/69) de positividad para $\mathrm{HPgV}$ por RPC-TR en comparación a 4,3\% (3/69) de muestras positivas para $\mathrm{VHC}^{71}$. De otra parte, Civardi y cols., analizaron 33 muestras de suero de pacientes con LNH del subtipo de células $B$, que eran positivas para marcadores de infección por VHC 
(RPC-TR y RIBA-2). En 1/33 (3\%) muestras se encontró positividad por RPC-TR para el HPgV mientras que 26/33 $(78,8 \%)$ se encontraron positivas para anticuerpos anti-E2 del HPgV. Adicionalmente, en este estudio se incluyeron muestras control pareadas de individuos sanos, en las que se detectaron frecuencias más bajas para la infección por $\mathrm{HPgV}$, de $2,8 \%$ para RP-TR y $35 \%$ para anticuerpos anti$\mathrm{E} 2$, con una diferencia estadísticamente significativa $(\times 2$ $\mathrm{p}<0,0001)^{72}$. En este estudio sólo se incluyeron muestras de suero de los pacientes, y adicionalmente no se evaluó la posibilidad de reacción cruzada con anticuerpos anti-VHC en el inmunoensayo por lo que los resultados no son del todo concluyentes. Pavlova y cols. en 1999, reportaron una frecuencia de detección de ARN (amplificación de la región 5'UTR y NS3) de HPgV de 72\% (21/29) en pacientes con neoplasias hematológicas, de los cuales $34 \%(10 / 29)$ correspondían a pacientes con LNH. En contraste, en los pacientes con enfermedades hematológicas no neoplásicas se encontró una frecuencia de $42 \%$ (8/19), con una diferencia estadísticamente significativa. De manera significante, se encontró una correlación positiva entre la infección por $\mathrm{HPgV}$ y la presencia de anormalidades citogenéticas (estructurales y numéricas) en $64 \%$ de los pacientes ${ }^{73}$.

Estos hallazgos se correlacionan con lo encontrado en regiones geográficas de baja prevalencia para $\mathrm{HPgV}$, donde se puede inferir una correlación entre la infección activa por $\mathrm{HPgV}$ y el riesgo de $\mathrm{LNH}^{74}$. Por su parte, Kaya y cols., en 2002 reportaron una frecuencia de detección en pacientes con $\mathrm{LNH}$ de $7,1 \%$ en comparación a individuos sanos $1,4 \%$, aunque esta diferencia no fue estadísticamente significativa $(\mathrm{p}>0,05)$; en este estudio se reportó que la infección por $\mathrm{HPgV}$ está asociada con un riesgo relativo de 5,3 veces de desarrollar $\mathrm{LNH}(95 \% \mathrm{CI}$ 0,61-48,39). Otro estudio, realizado en Grecia, evaluó la presencia de marcadores comparado con los controles. En este estudio la prevalencia de $\mathrm{VHC}$, tanto en los pacientes con LNH como en los controles, fue de $1,4 \%(1 / 70)^{75} \mathrm{de}$ infección por $\mathrm{VHC}$ y $\mathrm{HPgV}$, y se analizaron muestras de 120 pacientes con diagnóstico de LNH ( $90 \%$ del subtipo de células B), 1.342 muestras de donantes de sangre y 101 muestras de pacientes oncológicos avanzados con tumores sólidos y. En el caso de $\mathrm{HPgV}$, se demostró una prevalencia de $9,2 \%$ en pacientes con $\mathrm{LNH}$, específicamente del subtipo de células $\mathrm{B}$, en comparación a una baja prevalencia en los donantes de sangre y pacientes oncológicos $(0,7$ y $0,99 \%$, respectivamente) con una diferencia estadísticamente significativa. Los anticuerpos anti-VHC y ARN de VHC fueron detectados en una baja proporción de los tres grupos de pacientes analizados $(0,99-1,9 \%)$ sin diferencias estadísticamente significativas ${ }^{76}$. Estos hallazgos demuestran que la asociación entre VHC y LNH está influenciada por las diferencias geográficas y los resultados pueden diferir entre países de una misma región. Este mismo planteamiento se puede aplicar a lo observado para $\mathrm{HPgV}$ y LNH, con el fin de explicar las diferencias que diferentes estudios han reportado hasta la fecha.

Con el fin de establecer asociación, estudios analíticos recientes soportan con mayor confiabilidad un rol de este agente en el desarrollo de LNH. Un estudio de casos y controles realizado en Canadá, reportó mayor detección de ARN del HPgV en casos de LNH comparado con controles pareados por sexo, edad región y antecedentes de transfusión sanguínea ( 4,5 versus $1,8 \%$, respectivamente). Este estudio incluyó 553 pacientes con LNH y 438 controles, y reportó un riesgo relativo ajustado de 2,75, [1,22-6,69], indicando que el $\mathrm{HPgV}$ está asociado con un mayor riesgo de desarrollar LNH. Es de resaltar que, cuando se agruparon los casos de LNH y los controles de acuerdo a la historia de transfusión sanguínea, se mantuvo la significancia estadística entre la asociación de $\mathrm{HPgV}$ y $\mathrm{LNH}^{77}$.

Resultados concordantes fueron publicados por Chang y cols., en un estudio aleatorizado de casos (n: 658) y controles (n: 1.316) reclutados en E.U.A., donde se reportó una frecuencia de detección de $\mathrm{ARN}$ de $\mathrm{HPgV}$ de $1,8 \%$ en los casos vs $0,5 \%$ en los controles, con un riesgo relativo para $\mathrm{LNH}(\mathrm{OR}=3,43)$ y para $\mathrm{LNH}$ subtipo de células $\mathrm{B}(\mathrm{OR}=5,31)$. De forma significativa, en este estudio únicamente se encontró asociación con infección activa evidenciada por la detección de ARN viral; sin embargo, la positividad para anticuerpos anti-E2 no se asoció con el riesgo de LNH. Adicionalmente, se excluyeron pacientes co-infectados con VHI y/o VHC y se demostró que la infección por $\mathrm{HPgV}$ precedió el desarrollo de la enfermedad mediante la detección de ARN viral en las muestras antes del diagnóstico de $\mathrm{LNH}^{78}$. En contraste, otros estudios no han reportado resultados concluyentes acerca del papel del HPgV en LNH. Específicamente, el estudio de Guidicelli y cols., en el que se incluyeron 137 pacientes con LNH y 125 controles de diferentes regiones de Europa: Bellinzona (Suiza), Barcelona (España) y Southampton (Inglaterra), no logró demostrar una asociación entre el $\mathrm{HPgV}$ y el LNH. En este estudio, se evaluó la prevalencia de infección por $\mathrm{HPgV}$ mediante la detección de anticuerpos anti-E2, la cual osciló entre 13 y $22 \%$ en LNH, pero no se observó diferencia significativa respecto a la prevalencia en los controles. Para el análisis de estos resultados se debe tener en cuenta que estos controles no fueron pareados de acuerdo a los factores de riesgo y características sociodemográficas; adicionalmente en ninguna de las muestras se evaluó la presencia de ARN de $\mathrm{HPgV}$. En el caso de Southampton, no se incluyó un grupo control, por lo tanto, no se reportan resultados de la prevalencia del $\mathrm{HPgV}$ en esta población incluida en el estudio ${ }^{69}$. Igualmente, en una cohorte de pacientes co-infectados con VIH no se encontró asociación entre 
el $\mathrm{HPgV}$ y el desarrollo de linfoma, donde se reportó una prevalencia de ARN del $\mathrm{HPgV}$ de $30,3 \%$ en los pacientes con Linfoma Hodgkin y LNH, en comparación al grupo de pacientes sin linfoma $23,6 \%{ }^{10}$. En ambos estudios el número de casos de LNH fue bajo (n: 26) comparado con los anteriores, y no se especifica cuál fue el porcentaje de detección de $\mathrm{HPgV}$ en el grupo de LNH. En este sentido, otros estudios epidemiológicos en cohortes de pacientes con LNH y con infección por VIH son necesarios, que permitan demostrar qué factores intervienen en la asociación de $\mathrm{HPgV}$ y LNH en los pacientes que tienen infección por VIH.

\section{Conclusión}

El HPgV es un virus que cuenta con mecanismos de evasión de la respuesta inmune e inmunomodulación, que le permiten desarrollar persistencia viral en el hospedero. Se conoce que está ampliamente distribuido en la población a nivel mundial.

Teniendo en cuenta los hallazgos publicados hasta el momento, el papel de la infección por $\mathrm{HPgV}$ en el desarrollo de linfoma debe explorarse en más estudios con poblaciones de diferentes regiones geográficas. Factores virales como la diversidad genética, variantes con tropismo específico y factores patogénicos asociados a la persistencia, deben ser explorados más ampliamente con el fin de esclarecer el posible rol patogénico del $\mathrm{HPgV}$ en el desarrollo de enfermedad en humanos.

Es de resaltar que en algunas regiones de alta frecuencia de infección para el $\mathrm{HPgV}$ como Latinoamérica, no se han publicado datos de prevalencia en pacientes con enfermedades linfoproliferativas, incluido LNH, por lo que hasta la fecha se desconoce cómo es la dinámica de $\mathrm{HPgV}$ en pacientes con $\mathrm{LNH}$ en nuestra región. Adicionalmente, no se han publicado estudios de caracterización molecular que incluyan el análisis del genotipo, variabilidad genética y carga viral, entre otros. Es así que, el desarrollo de estudios experimentales con el fin de explorar mecanismos de persistencia, así como potenciales mecanismos oncogénicos, permitirán ampliar el conocimiento del potencial patogénico del $\mathrm{HPgV} \mathrm{y} \mathrm{su}$ efecto en la salud humana.

Agradecimientos. Los autores agradecen al Instituto Tecnológico Metropolitano por la financiación (Proyecto P14225).

\section{Resumen}

El pegivirus humano $(\mathrm{HPgV})$ es un virus $\mathrm{ARN}$ que fue identificado en el año 1995. Actualmente se encuentra clasificado dentro de la familia Flaviviridae, género Pegivirus, relacionado filogenéticamente con el virus de la hepatitis $\mathrm{C}$ (VHC). El HPgV es un virus linfotrópico, con replicación en médula ósea, tejidos linfoides, y en células mononucleares de sangre periférica. Este virus se transmite por vía parenteral y sexual. Según estimaciones realizadas, en el mundo existen alrededor de 750 millones de personas infectadas por este agente. Se ha evidenciado que hasta en $25 \%$ de los casos se presenta una infección persistente, y aunque se considera que el $\mathrm{HPgV}$ es un virus no patogénico, existen evidencias epidemiológicas que sugieren una relación con el desarrollo de desórdenes linfoproliferativos, particularmente linfoma no Hodgkin (LNH). Algunos estudios han reportado una alta prevalencia de $\mathrm{HPgV}$ en pacientes con $\mathrm{LNH}$ comparado con donantes de sangre y/o pacientes con enfermedades hematológicas no malignas, lo que se asocia a un incremento en el riesgo relativo para el desarrollo de $\mathrm{LNH}$ en personas infectadas. De otra parte, existen estudios epidemiológicos que contradicen esta asociación, por lo que el rol de HPgV en la aparición de desórdenes lifoproliferativos es un tema actual de debate. En el presente manuscrito se discute el potencial patogénico derivado de los mecanismos de infección persistente del $\mathrm{HPgV}$, así como las principales evidencias sobre la relación entre el $\mathrm{HPgV}$ y el riesgo de desarrollo de LNH.

\section{Referencias bibliográficas}

1.- Stapleton J T, Foung S, Muerhoff A S, Bukh J, Simmonds P. The GB viruses: A review and proposed classification of GBV-A, GBV-C (HGV), and GBV-D in genus Pegivirus within the family Flaviviridae. J Gen Virol 2011; 92: 233-46. doi: 10.1099/vir.0.027490-0. Epub 2010 Nov 17.

2.- George S L, Varmaz D, Stapleton J T. GB virus $\mathrm{C}$ replicates in primary $\mathrm{T}$ and $\mathrm{B}$ lymphocytes. J Infect Dis 2006; 193; 451-4. DOI: 10.1086/499435.

3.- Bhattarai N, Stapleton J T. GB virus C: The good boy virus? Trends Microbiol 2012; 20:
124-30. doi: 10.1016/j.tim.2012.01.004. Epub 2012 Feb 8.

4.- Arroyave J C, Pujol F H, Navas M C, CortésMancera F. Interacción entre el virus de la inmunodeficiencia humana y el virus GB tipo-C durante el estado de co-infección. Rev Chilena Infectol 2013; 1: 31-41. http://dx.doi. org/10.4067/S0716-10182013000100005.

5.- Xiang J. Martínez-Smith C, Gale Jr M, Chang Q, Labrecque D R, Schmidt W N, et al. GB virus type C NS5A sequence polymorphisms: association with interferon susceptibility and inhibition of PKR-mediated eIF2alpha phosphorylation. J Interferon Cytokine Res 2005; 25: 261-70. https://doi.org/10.1089/ jir.2005.25.261.

6.- Stapleton J T, Xiang J, McLinden J H, Bhattarai N, Chivero E T, Klinzman D, et al. A novel T cell evasion mechanism in persistent RNA virus infection. Trans. Am Clin Climatol Assoc 2014; $125 ; 14-24$.

7.- Msuko K, Mitsui T, Iwano K E. a. Infection with hepatitis $\mathrm{Gb}$ virus $\mathrm{C}$ in patients on maintenance hemodialysis. J Med 1996; 334: 6-11.

8.- Stapleton J T, Chaloner K. GB virus C infection and non-Hodgkin lymphoma: important to know but the jury is out. Int J Cancer 2010; 2761: 2759-61.

9.- Sathar M A, Soni P N. GB Virus C/Hepatitis 
G Virus (GBV-C/HGV): still looking for a disease. Int J Exp Pathol 2000; 81 (5): 305-22. https://dx.doi.org/10.1111\%2Fj.13652613.2000.00166.x.

10.- Ernst D, Pischke S, Greer M, Wedemeyer H, Stoll M. No increased incidence for GB-virus C infection in a cohort of HIV-positive lymphoma patients. Int J Androl 2011; 128: 3012.

11.- Michaelis S, Kazakov V, Schmid M, Dummer R, Burg G, Kempf W. Hepatitis C and G viruses in B-cell lymphomas of the skin. J Cutan Pathol 2003; 30: 369-72.

12.- Muerhoff A S, Leary T P, Simons J N, PilotMatias T J, Dawson G J, Erker J C, et al. Genomic organization of GB viruses A and $B$ : two new members of the Flaviviridae associated with GB agent hepatitis. J Virol 1995; 69: 5621-30.

13.- Yoshiba M, Okamoto H, Mishiro S. Detection of the GBV-C hepatitis virus genome in serum from patients with fulminant hepatitis of unknown aetiology. Lancet 1995; 346: 1131-2.

14.- Simons JN, Pilot-Matias T J, Leary T P, Dawson G J, Desai SM, Schlauder G G, et al. Identification of two flavivirus-like genomes in the GB hepatitis agent. Proc Natl Acad Sci USA 1995; 92: 3401-5.

15.- Fiordalisi G, Zanella I, Mantero G, Bettinardi A, Stellini R, Paraninfo G, et al. High prevalence of GB virus $\mathrm{C}$ infection in a group of Italian patients with hepatitis of unknown etiology. J Infect Dis 1996; 174; 181-3.

16.- Pinho J R R, Da Silva LC. Invited review GB virus $C$ /hepatitis $G$ virus and other putative hepatitis non A-E viruses. Rev Inst Med Trop Sao Paulo 1996; 38: 441-50.

17.- Chams V, Fournier-Wirth C, Chabanel A, Hervé P, Trépo C. Le virus GB-C ou virus «dit» de l'hépatite $\mathrm{G}$ est-il impliqué en pathologie humaine? Transfus. Clin Biol 2003; 10: 292306 .

18.- Cheung R C, Keeffe E B, Greenberg H B. Hepatitis $G$ virus: is it a hepatitis virus? West J Med 1997; 167: 23-33.

19.- Chivero E T, Bhattarai N, Rydze R T, Winters M A, Holodniy M, Stapleton J T, et al. Human pegivirus RNA is found in multiple blood mononuclear cells in vivo and serumderived viral RNA-containing particles are infectious in vitro. J Gen Virol 2014; 95: 1307 19. doi: 10.1099/vir.0.063016-0. Epub 2014 Mar 25.

20.- Arroyave J C, Pujol F H, Navas M C, CortésMancera F M. Interaction between HIV-1 and GB virus type-C during coinfection status. Rev Chilena Infectol 2013; 30: 31-41.

21.- Pujol F H, Khudyakov Y E, Devesa M, Cong M E, Loureiro C L, Blitz L, et al. Hepatitis G virus infection in Amerindians and other Venezuelan high-risk groups. J Clin Microbiol 1998; 36 : 470-4.

22.- Kao J H, Chen P J, Hsiang S C, Chen W,
Chen D S. Phylogenetic analysis of GB virus C: comparison of isolates from Africa, North America, and Taiwan. J Infect Dis 1996; 174: 410-3.

23.- Muerhoff A S, Leary T P, Sathar M A, Dawson G J, Desai S M. African origin of GB virus $C$ determined by phylogenetic analysis of a complete genotype 5 genome from South Africa. J Gen Virol 2005; 86: 1729-35. DOI: 10.1099/vir.0.80854-0

24.- Naito H, Hayashi S, Abe K. The entire nucleotide sequence of two hepatitis $\mathrm{G}$ virus isolates belonging to a novel genotype: Isolation in Myanmar and Vietnam. J Gen Virol 2000; 81: 189-94.

25.- Feng Y, Zhao W, Feng Y, Dai J, Li Z, Zhang $\mathrm{X}$, et al. A novel genotype of GB virus C: its identification and predominance among injecting drug users in Yunnan, China. PLoS One 2011; 6: e21151. doi: 10.1371/journal. pone.0021151. Epub 2011 Oct 6 .

26.- Alvarado-Mora M V M V, Botelho L, Nishiya A, Neto R A, Gomes-Gouvêa M S, Gutiérrez, M F, et al. Frequency and genotypic distribution of GB virus C (GBV-C) among Colombian population with Hepatitis B (HBV) or Hepatitis C (HCV) infection. Virol J 2011; 8: 345. doi: 10.1186/1743-422X-8-345.

27.- Giret M T M, Miraglia J L, Sucupira A, Nishiya A, Levi J E, Díaz R S, et al. Prevalence, incidence density, and genotype distribution of GB virus $\mathrm{C}$ infection in a cohort of recently HIV-1-infected subjects in Sao Paulo, Brazil. Plos One 2011; 6, (2011). https:// doi.org/10.1371/journal.pone.0018407.

28.- Naito H, Abe K. Genotyping system of GBV-C/ HGV type 1 to type 4 by the polymerase chain reaction using type-specific primers and geographical distribution of viral genotypes. $\mathbf{J}$ Virol 2001; 91: 3-9.

29.- Stapleton J T, Williams C F, Xiang J. Minireview GB virus type C: a beneficial infection? J Clin Microbiol 2004; 42: 3915-9. DOI: 10.1128/JCM.42.9.39153919.2004

30.- Ranjbar M M, Ghorban K, Alavian S M, Keyvani H, Dadmanesh M, Ardakany A R, et al. GB virus $\mathrm{C} /$ hepatitis $\mathrm{G}$ virus envelope glycoprotein E2: Computational molecular features and immunoinformatics study. Hepat. Mon. 2013; 13: 1-14. doi: 10.5812/ hepatmon. 15342 .

31.- Boodram B, Hershow R C, Klinzman D, Stapleton J T. GB virus C infection among young, HIV-negative injection drug users with and without hepatitis $\mathrm{C}$ virus infection. J Viral Hepat 2011; Apr 18 (4): e153-9. doi: 10.1111/j.1365-2893.2010.01350.x

32.- Samarbaf-Zadeh A R, Makvandi M, Hamadi A, Kaydani G A, Absalan A, Afrough P, et al. Prevalence of hepatitis G virus among hemodialysis and kidney transplant patients in Khuzestan province,
Iran. Jundishapur J Microbiol 2015; 8: e20834. doi: 10.5812/jjm.20834. eCollection 2015.

33.- Pessoa Ma G, Terrault N A, Detmer J, Kolberg A, Collins M, Hassoba H, et al. Quantitation of hepatitis $\mathrm{G}$ and $\mathrm{C}$ viruses in the liver: evidence that hepatitis $\mathrm{G}$ virus is not hepatotropic. Hepatology 1995; 27: 877-80.

34.- Boisvert J, He X, Cheung R, Keeffe E B, Wright T. Quantitative analysis of hepatitis $C$ virus in peripheral blood and liver: replication detected only in liver. J Infect Dis 2001; 184 : 827-35. https://doi.org/10.1086/323391

35.- Seipp S, Hofmann W J, Tax U, Theilmann L, Goeser T. Hepatotropism of GB virus C (GBVC): GBVC replication in human hepatocytes and cells of human hepatoma cell lines. J Hepatol 1999; 30: 570-9.

36.- Petrik J, Guella L, Wight D G, Pearson G M, Hinton J, Parker H, et al. Hepatic histology in hepatitis $\mathrm{C}$ virus carriers coinfected with hepatitis G virus. Gut 1998; 42: 103-6.

37.- Laskus T, Radkowski M, Wang L, Vargas H, Rakela J. Lack of evidence for hepatitis $\mathrm{G}$ virus replication in the livers of patients coinfected with hepatitis $C$ and G viruses. J Virol 1997; 71: 7804-6.

38.- Berg T, Mülle A R, Platz K P, Höhne M, Bechstein W O, Hopf U, et al. Dynamics of GB virus $\mathrm{C}$ viremia early after orthotopic liver transplantation indicates extrahepatic tissues as the predominant site of $\mathrm{GB}$ virus $\mathrm{C}$ replication. Hepatol. Gastroenterol 1999; 29: 245-9.

39.- George S L, Varmaz D, Stapleton J T. GB virus $\mathrm{C}$ replicates in primary $\mathrm{T}$ and $\mathrm{B}$ lymphocytes. J Infect Dis 2006; 193: 451-4. DOI: $10.1086 / 499435$

40.- Chivero E T, Stapleton J T. Tropism of human pegivirus (formerly known as $\mathrm{GB}$ virus $\mathrm{C} /$ hepatitis $\mathrm{G}$ virus) and host immunomodulation : insights into a highly successful viral infection. J Gen Virol 2016; 96: 1521-32. doi: 10.1099/ vir.0.000086. Epub 2015 Feb 9.

41.- Kisiel E, Caraballo K, Pawelczyk A, Bukowska I, Kubisa N, Laskus T, et al. Hepatitis G virus/GBV-C in serum, peripheral blood mononuclear cells and bone marrow in patients with hematological malignancies. Infect Genet Evol 2013; 19: 195-9. https://doi.org/10.1016/j. meegid.2013.07.010.

42.- Radkowski M, Kubicka J, Kisiel E, Cianciara J, Nowicki M, Rakela J, et al. Detection of active hepatitis $\mathrm{C}$ virus and hepatitis $\mathrm{G}$ virus/GB virus $\mathrm{C}$ replication in bone marrow in human subjects. Blood 2000; 95: 3986-9.

43.- Chivero E T, Stapleton J T. Tropism of human Pegivirus (formerly known as $\mathrm{GB}$ virus $\mathrm{C} /$ hepatitis $\mathrm{G}$ virus) and host immunomodulation: insights into a highly successful viral infection. J Gen Virol 2015; 1521-32. doi:10.1099/ vir.0.000086.

44.- Giménez-Barcons M, Sánchez-Fueyo A, Ampurdanés S, Puig-Basagoiti F, Guilera M, 
Ibáñez A, et al. Genetic evolution of GB virus $\mathrm{C} /$ hepatitis $\mathrm{G}$ virus (GBV-C/HGV) under interferon pressure. Antiviral Res 2000; 46: $157-70$.

45.- Kao J H, Lai M Y, Chen W, Chen P J, Chen D S. Brief communication: Efficacy of ribavirin plus interferon alpha on viraemia of GB virus-C/hepatitis $\mathrm{G}$ virus: Comparison with interferon alpha alone. J Gastroenterol Hepatol 1998; 13: 1249-53.

46.- Rydze R T, Xiang J, McLinden J H, Stapleton $\mathrm{J}$ T. GB virus type $\mathrm{C}$ infection polarizes T-cell cytokine gene expression toward a Th1 cytokine profile via NS5A protein expression. J Infect Dis 2012; 206: 69-72. doi: 10.1093/ infdis/jis312. Epub 2012 Apr 25.

47.- Xiang J, McLinden J H, Chang Q, Kaufman T M, Stapleton J T. An 85-aa segment of the GB virus type C NS5A phosphoprotein inhibits HIV-1 replication in CD4+ Jurkat T cells. Proc Natl Acad Sci USA 2006; 103: 15570-5. DOI: $10.1073 /$ pnas.0604728103

48.- Xiang J, Mclinden J H, Chang Q, Jordan E L, Stapleton J T. Characterization of a peptide domain within the GB virus C NS5A phosphoprotein that inhibits HIV replication. Plos One 2008; 3: 3-12 https://doi.org/10.1371/ journal.pone.0002580.

49.- Schwarze-Zander C, Blackard J T, Rockstroh $\mathrm{J} \mathrm{K}$. Role of GB virus $\mathrm{C}$ in modulating HIV disease. Expert Rev Anti Infect Ther 2012; 10: 563-72. doi: 10.1586/eri.12.37.

50.- Lauck M, Bailey A L, Andersen K G, Goldberg T L, Sabeti P C, O'Connor D H. GB virus C coinfections in West African Ebola patients. J Virol 2015; 89: 2425-9 doi: 10.1128/JVI.0275214. Epub 2014 Dec 3.

51.- Chowdhury A Y, Tavis J E, George S L. Human pegivirus (GB virus C) NS3 protease activity inhibits induction of the type I interferon response and is not inhibited by $\mathrm{HCV}$ NS3 protease inhibitors. Virology 2014; 456457: 300-9. doi: 10.1016/j.virol.2014.03.018. Epub 2014 Apr 24.

52.- Hjalgrim H, Engels E A. Infectious aetiology of Hodgkin and non-Hodgkin lymphomas: A review of the epidemiological evidence. J Intern Med 2008; 264: 537-48. doi: 10.1111/j.13652796.2008.02031.x

53.- Campo E, Swerdlow Steven H, Harris N L, Pileri S, Stein H, Jaffe, et al. The 2008 WHO classification of lymphoid neoplasms and beyond: evolving concepts and practical applications. Blood 2011; 117: 5019-32. doi: 10.1182/blood-2011-01-293050

54.- American Cancer Society. Global Cancer Facts and Figures 3rd Edition (2015).

55.- Laurini J A. Perry A M, Boilesen E, Diebold J, Maclennan K A, Müller-Hermelink H K, et al. Classification of non-Hodgkin lymphoma in Central and South America: a review of 1028 cases Classification of non-Hodgkin lymphoma in Central and South America: a review of 1028 cases. Blood. 2012; 120 (24): 4795-801 doi: 10.1182/blood-2012-07-440073. Epub 2012 Oct 18.

56.- Diumenjo M C, Abriata G, Forman D, Sierra M S. The burden of non-Hodgkin lymphoma in Central and South America. Cancer Epidemiol 2016; 44: S168-S177. doi: 10.1016/j. canep.2016.05.008.

57.- IARC. Biological Agents. IARC monographs on the evaluation of carcinogenic risk to humans. 100B, International Agency for Research on Cancer, 2012. http://monographs. iarc.fr/ENG/Monographs/vol100B/mono100B. pdf

58.- Engels E A. Infectious agents as causes of non-Hodgkin lymphoma. Cancer Epidemiol. Biomarkers Prev 2007; 16: 401-5. DOI: 10.1158/1055-9965.EPI-06-1056

59.- El Ghissassi F, Baan R, Straif K, Grosse Y, Secretan B, Bouvard V, et al. A review of human carcinogens-Part D: radiation. The Lancet Oncol 2009; 10 (8): 751.2.

60.- Ekström-Smedby K. Epidemiology and etiology of non-Hodgkin lymphoma-a review. Acta Oncol (Madr) 2006; 45: 258-71. DOI: $10.1080 / 02841860500531682$

61.- Marcucci F, Mele A. Hepatitis viruses and non-Hodgkin lymphoma: epidemiology, mechanisms of tumorigenesis, and therapeutic opportunities. Blood Rev 2016; 117: 1792-9. doi: 10.1182/blood-2010-06-275818. Epub 2010 Oct 19.

62.- Gisbert J P, García-Buey L, Pajares J M, Moreno-Otero R. Prevalence of hepatitis C virus infection in porphyria cutanea tarda: Systematic review and meta-analysis. J Hepatol 2003; 39: 620-7.

63.- Dal Maso L, Franceschi S. Hepatitis C virus and risk of lymphoma and other lymphoid neoplasms: A meta-analysis of epidemiologic studies. Cancer Epidemiol. Biomarkers Prev 2006; 15: 2078-85. DOI: 10.1158/1055-9965. EPI-06-030

64.- Arroyave O J C, Álvarez C, Correa G, Balcázar N, Arbeláez M P. Navas M. Infección por el virus de la hepatitis $\mathrm{C}$ en individuos transfundidos antes de 1994 en Antioquia, Colombia. Rev Colomb Gastroenterol 2014; 29 (4): 383-9.

65.- Salvatierra K, Florez H. Análisis del virus de la hepatitis $\mathrm{C}$ en pacientes en hemodiálisis. Infectio 2016; 20: 130-7. https://doi. org/10.1016/j.infect.2015.10.002.

66.- Kawamura Y, Ikeda K, Arase Y, Yatsuji H, Sezaki H, Hosaka T, et al. Viral elimination reduces incidence of malignant lymphoma in patients with hepatitis C. Am J Med 2007; 120: 1034-41. DOI: 10.1016/j.amjmed.2007.06.022

67.- De Renzo A, Persico E, de Marino F, di Giacomo Russo G, Notaro R, di Grazia C, et al. High prevalence of hepatitis $\mathrm{G}$ virus infection in Hodgkin's disease and B-cell lymphoproliferative disorders: absence of correlation with hepatitis $\mathrm{C}$ virus infection. Haematologica 2002; 87: 714-8.

68.- Keresztes K, Takács M, Horányi M, Miltényi Z, Illés Á. HCV and HGV Infection in Hodgkin's Disease. Pathol Oncol Res 2003; 9: 222-5. DOI:

PAOR.2003.9.4.0222

69.- Guidicelli S N, López-Guillermo A, Falcone U, Conconi A, Christinat A, RodríguezAbreu D, et al. Hepatitis $\mathrm{C}$ virus and GBV-C virus prevalence among patients with $\mathrm{B}$-cell lymphoma in different European regions: a case-control study of the International Extranodal Lymphoma Study Group. Hematol Oncol 2012;30(3):137-42. doi: 10.1002/ hon.1015. Epub 2011 Nov 21.

70.- Fogeda M, López-Alcorocho J M, Bartolomé J, Arocena C, Martin M A, Carreno V. Existence of distinct $\mathrm{GB}$ virus $\mathrm{C} /$ hepatitis $\mathrm{G}$ virus variants with different tropism. J Virol 2000; 74: 793642.

71.- Ellenrieder V. Weidenbach H, Frickhofen N, Michel De, Beckh K. HCV and HGV in B-cell non-Hodgkin's lymphoma. J Hepatol 1998; 28; 34-9.

72.- Civardi G, Tanzi E, Ferrari B, Vallisa D, Zanetti A, Cavanna L. High prevalence of anti-HGV/ E2 antibodies in HCV-positive patients with non Hodgkin's lymphoma. Haematologica 1998; 83: 957-8.

73.- Pavlova B G. Heinz R, Selim U, Tu H, Pittermann E, Eder G. Association of GB virus $\mathrm{C}(\mathrm{GBV}-\mathrm{C})$ /hepatitis $\mathrm{G}$ virus (HGV) with haematological diseases of different malignant potential. J Med Virol 1999; 57 : 361-6.

74.- Wiwanitkit V. Individuals with HGV-RNA are at high risk of B cell non-Hodgkin's lymphoma development. Asian Pacific J Cancer Prev 2005; 6: 215-6.

75.- Kaya H, Erdem F, Gu M. Prevalence of hepatitis $\mathrm{C}$ virus and hepatitis $\mathrm{G}$ virus in patients with non-Hodgkin's lymphoma. Clin Lab Haem 2002; 24: 107-10.

76.- Giannoulis E. Economopoulos T, Mandraveli K, Giannoulis K, Nikolaides C, Zervou $\mathrm{E}$, et al. The prevalence of hepatitis $\mathrm{C}$ and hepatitis $\mathrm{G}$ virus infection in patients with $\mathrm{B}$ cell non-Hodgkin lymphomas in Greece: A Hellenic Cooperative Oncology Group study. Acta Haematol 2004; 112: 189-93. https://doi. org $/ 10.1159 / 000081270$

77.- Krajden M, Yu A, Braybrook H, Lai A S, Mak A, Chow R, et al. GBV-C/hepatitis G virus infection and non-Hodgkin lymphoma: A case control study. Int J Cancer 2010; 126: 2885-92. DOI: $10.1002 /$ ijc. 25035

78.- Chang C M. Stapleton J T, Klinzman D, McLinden J H, Purdue M P, Katki H A, et al. GBV-C infection and risk of NHL among U.S. adults. Cancer Res 2014: 74: 5553-60. doi: 10.1158/0008-5472.CAN-14-0209. Epub 2014 Aug 12. 